\title{
Original
}

\section{Regulatory Effect of IL-4 on Early Th17 Differentiation from Naive T Cells into Stem Cell Memory Th17 Precursors via Modulation of CD31 and CCR6 Expression}

\author{
Kohei MaEdA, Toshihiro TANioKa and Sanju Iwamoto*
}

\begin{abstract}
Although antigen-specific $\mathrm{T}$ helper (Th) cells are developed from naive $\mathrm{T}$ cells, human Th17 cells are not derived from naive $\mathrm{CD}^{+} \mathrm{T}$ cells unlike murine cells. Therefore, the source of human Th17 cells has remained unresolved. In this study, we assessed the early differentiation pathway of human Th17 cells from $\mathrm{CD} 1^{+}$thymic naive $\mathrm{T}$ cells into stem cell memory $\mathrm{CCR}^{+} \mathrm{Th} 17$ precursors and the regulation of this process by cytokines. Peripheral blood mononuclear cells were isolated from healthy volunteers. We found that only $\mathrm{CD}^{-} 1^{-} \mathrm{CCR}^{+}$naive type $\mathrm{CD}^{+} \mathrm{T}$ cells had the ability to produce IL-17A in response to Th17-inducing stimuli. A cell tracking assay using $\mathrm{CD} 1^{+} \mathrm{CCR}^{-}$cells labeled with carboxyfluorescein diacetate succinimidyl ester revealed that $\mathrm{CD}^{2} 1^{-} \mathrm{CCR}^{+} \mathrm{Th} 17$ precursors were derived from $\mathrm{CD} 1^{+} \mathrm{CCR}^{-}$thymic naive $\mathrm{T}$ cells. CD31 is known to suppress IL-17 production by interfering with downstream $\mathrm{T}$ cell receptor (TCR) signaling molecules including Lck, which is essential for IL-17 production. The inactive form of Lck was much higher in $\mathrm{CD} 31^{+} \mathrm{T}$ cells than $\mathrm{CD} 31^{-} \mathrm{T}$ cells after TCR stimulation. In experiments of cytokine-mediated modulation of Th17 cell differentiation, IL-4 suppressed the conversion of $\mathrm{CD} 31^{+} \mathrm{CCR}^{-}$naive $\mathrm{T}$ cells into $\mathrm{CD}^{-} 1^{-} \mathrm{CCR}^{+}$ Th17 precursors by upregulating CD31 expression and suppressing CCR6 expression. In conclusion, $\mathrm{CD} 31^{-} \mathrm{CCR}^{+} \mathrm{Th} 17$ precursors could be sourced from CD $31^{+}$ $\mathrm{CCR}^{-}$naive $\mathrm{T}$ cells, and IL-4 regulated the early Th17 differentiation. Our findings provide novel insights into the regulation of differentiation of naive $\mathrm{CD} 4^{+}$ $\mathrm{T}$ cells into Th17 cells in humans. Furthermore, our results may provide hints for further elucidation of the differentiation process of Th17 cells and of the pathology of Th17 cell-related diseases.
\end{abstract}

Key words : Th17 cells, IL-4, CD31, CCR6, TSCM cells

\section{Introduction}

$\mathrm{CD}^{+}$naive $\left(\mathrm{CD}^{+} 5 \mathrm{RA}^{+} \mathrm{CD}^{+} 5 \mathrm{RO}^{-} \mathrm{CCR}^{+}\right) \mathrm{T}$ cells activated by antigen presenting cells via the major histocompatibility complex-class 2 differentiate into helper $\mathrm{T}$ (Th) cells through the regulation of the cytokine environment by factors such as IL-12 and IL-4. According to the Th1/Th2 paradigm, Th1 cells are involved in immune activation including pathological responses by pro-

Department of Pharmacology, Toxicology and Therapeutics, Division of Physiology and Pathology, Showa University School of Pharmacy, 1-5-8 Hatanodai, Shinagawa-ku, Tokyo 142-8555, Japan.

* To whom corresponding should be addressed. 
ducing IFN- $\gamma$, while Th2 cells are involved in allergic immune activation by producing IL-4, IL-5 and IL-10. Each Th subset counteracts their differentiation through antagonistic interactions ${ }^{1)}$. However, Langrish et al found that IL-17-producing $\mathrm{CD}^{+} \mathrm{T}$ (Th17) cells played a pathogenic role in the experimental autoimmune encephalomyelitis (EAE), a disease model for multiple sclerosis in humans ${ }^{2)}$. The finding disrupted the Th1/Th2 paradigm and highlighted the role of Th17 cells in the pathogenesis of autoimmune diseases.

In addition to their involvement in multiple sclerosis, Th17 cells may be the pathogenic Th subset for various human autoimmune diseases including psoriasis ${ }^{3)}$, rheumatoid arthritis ${ }^{4)}$, and ulcerative colitis ${ }^{5)}$. Th17 cells form a distinct lineage of $\mathrm{CD}^{+} \mathrm{T}$ cells since each $\mathrm{Th}$ subset expresses a different transcription factor, also known as a master regulator, which is involved in differentiation. Retinoic acid-related orphan receptor gamma $t(\mathrm{ROR} \gamma \mathrm{t}$ ) plays the role of master regulator for Th17 cells ${ }^{6}$, although the role of RORC2, the human ortholog of $\mathrm{ROR} \gamma \mathrm{t}$, as the master regulator in humans remains unclear ${ }^{7)}$. Furthermore, IFN- $\gamma$ and IL-4 inhibit the differentiation of naive $\mathrm{T}$ cells into Th17 cells, like the way in which Th1/Th2 cells suppress each other ${ }^{8,9)}$. However, unlike in mice, human Th17 cells are not directly induced from naive CD4 ${ }^{+}$ $\mathrm{T}$ cells ${ }^{10)}$. Thus, human Th17 cells may mature from naive $\mathrm{T}$ cells via some precursor, but this differentiation pathway is unclear. Recently, it was revealed that human Th17 cells had been induced from $\mathrm{CD}^{4} \mathrm{RA}^{+} \mathrm{CCR}^{+}$naive type $\mathrm{T}$ cells ${ }^{11)}$. These cells have memory phenotypes of newly identified stem cell memory $\mathrm{T}\left(\mathrm{T}_{\mathrm{SCM}}\right)$ cells whose multipotency differs from that observed in conventional naive $\mathrm{T}$ cells ${ }^{12)}$.

CD31 is expressed on vascular endothelial cells, platelets, and some lymphocytes; it is also involved in cell adhesion ${ }^{13)}$. Naive $\mathrm{T}$ cells expressing CD31 that matured in the thymus and recently entered the peripheral blood are known as recent thymic emigrants or thymic naive $\mathrm{T}$ cells ${ }^{14)}$. Although the $\mathrm{T}$ cell delivery function of the thymus weakens with aging, the number of naive $\mathrm{T}$ cells in the peripheral blood of healthy adults is maintained for a long time ${ }^{15)}$ by homeostatic proliferation (HP) ${ }^{16,17)}$. Naive $\mathrm{T}$ cells that have undergone HP exhibit downregu-

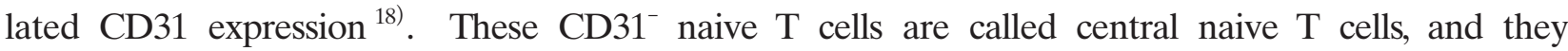
are more pathogenic than thymic naive $\mathrm{T}$ cells ${ }^{14)}$. CD31 contains an immunoreceptor tyrosinebased inhibition motif (ITIM) in the intracellular domain and binds the Src homology 2 domain-bearing protein tyrosine phosphatase-2 (SHP-2) which suppresses T cell receptor (TCR) signaling ${ }^{19)}$. Therefore, we considered whether CD31 may be interfering with the differentiation from naive $\mathrm{T}$ cells into Th17 cells, and whether downregulation of CD31 may be necessary during the early stages of human Th17 differentiation to induce $\mathrm{T}_{\mathrm{SCM}}$ cells.

In this study, we assessed the early differentiation pathway of Th17 cells from thymic naive $\mathrm{T}$ cells into stem cell memory Th17 precursors and the regulation of the process by IL-4 in humans. At the time of this writing, the early stages of the Th17 differentiation pathway have not been well-studied in mice. Our results yield novel insights into the regulation of the early stages of Th17 differentiation and may provide clues regarding the pathogenesis of Th17-related diseases. 


\section{Materials and methods}

\section{Human Samples}

This study was approved by the School of Medicine, Showa University Ethical Committee (Tokyo, Japan) (Approval number: 1382). Samples were obtained from healthy volunteers from Showa University. Informed consent was obtained from all subjects.

\section{Isolation of Lymphocytes}

Human peripheral blood mononuclear cells were isolated from heparinized blood using density gradient centrifugation with Leucosep ${ }^{\circledR}$ (Greiner Bio-One, Kremsmünster, Austria) and HISTOPAQUIE $^{\circledR}-1077$ (Sigma-Aldrich, St. Louis, MO, USA). CD4 ${ }^{+}$cells were isolated from peripheral blood mononuclear cells (PBMCs) via positive selection using anti-human CD4 microbeads (Miltenyi Biotec, Bergisch Gladbach, Germany).

\section{Cell Culture}

The anti-CD3/CD28 antibodies (BioLegend, San Diego, CA, USA) were used to activate proliferation of lymphocytes. These antibodies were diluted with ice-cold PBS containing $2 \mathrm{mg} / \mathrm{ml}$ BSA to $10 \mu \mathrm{g} / \mathrm{ml}$, and the culture plate was coated with this solution and incubated for at least $4 \mathrm{~h}$ at $4{ }^{\circ} \mathrm{C}$. After aspiration of the diluted solutions, sorted T cells $\left(1-2 \times 10^{5} / \mathrm{ml}\right)$ (purity of $\geq$ 95\%) were seeded on this culture plate; $10 \mathrm{ng} / \mathrm{ml}$ of the IL-1 $\beta$, IL-23, IL-12, IL-4 (BioLegend) and $2 \mathrm{ng} / \mathrm{ml}$ of the TGF- $\beta 1$ (BioLegend) were then added to the culture plate. The culture medium was composed of Iscove's modified Dulbecco's medium (IMDM) $(1 \times)$ (Thermo Fisher Scientific, Waltham, MA, USA) supplemented with L-glutamine, $25 \mathrm{mM} \mathrm{HEPES,} 5 \% \mathrm{CTS}^{\mathrm{TM}}$ Immune Cell SR (Thermo Fisher Scientific), and penicillin (100 U/ml)-streptomycin $(100 \mu \mathrm{g} / \mathrm{ml})$ (FujiFilm Wako Pure Chemical Corporation, Osaka, Japan). Th17-inducing stimuli were defined as cytokines including IL-1 $\beta$ and IL-23.

\section{Fluorescence Activated Cell Sorting (FACS)}

The cells were analyzed using BD FACSAria ${ }^{\mathrm{TM}}$ II (Becton, Dickinson and Company, Franklin Lakes, NJ, USA) with BD FACSDiva ${ }^{\mathrm{TM}}$ (Becton, Dickinson and Company). We used the following fluorescently labeled monoclonal antibodies: Pacific Blue ${ }^{\mathrm{TM}}$ anti-human CD3, clone HIT3a; Brilliant Violet $510^{\mathrm{TM}}$ anti-human CD4, clone A161A1; APC anti-human CD31, clone WM59; PE anti-human CD45RO, clone UCHL1; PerCP / Cyanine5.5 anti-human CD45RA, clone HI100; Alexa Fluor ${ }^{\circledR} 488$ anti-human CD197 (CCR7), clone G043H7; APC/Cy7 anti-human TCR V $\alpha$ 7.2, clone 3C10; PE / Cy7 anti-human CD196 (CCR6), clone G034E3; Alexa Fluor ${ }^{\circledR} 488$ antihuman IL-17A, clone BL168; Pacific Blue ${ }^{\mathrm{TM}}$ anti-human IFN- $\gamma$, clone 4S.B3 (BioLegend) ; Alexa Fluor ${ }^{\circledR} 647$ Mouse anti-Lck (pY505) ; PE Mouse anti-Lck, clone MOL171 (Becton, Dickinson and Company). The negative controls lacked the fluorescently labeled monoclonal antibodies. 


\section{Intracellular Staining}

Before intracellular staining for FACS analysis, the cultured $\mathrm{T}$ cells were stimulated using phorbol 12-myristate 13-acetate (PMA) (Sigma-Aldrich) (final concentration $40 \mathrm{ng} / \mathrm{ml}$ ) and ionomycin (Sigma-Aldrich) (final concentration $4 \mu \mathrm{g} / \mathrm{ml}$ ) for $1 \mathrm{~h}$. Subsequently, brefeldin A (SigmaAldrich) (final concentration $4 \mu \mathrm{g} / \mathrm{ml}$ ) was added and incubated for $2 \mathrm{~h}$. The stimulated cells were then fixed and permeabilized using the FOXP3 fix/perm buffer set (BioLegend) according to the manufacturer's protocol. Surface antigens were pre-stained for $30 \mathrm{~min}$ before performing the fix/perm process using appropriate fluorescently labeled antibodies to permit simultaneous analysis of surface antigens and intracellular cytokines.

\section{Assay of pY505-Lck detection}

CD31 positive or negative naive $\mathrm{CD}^{+} \mathrm{T}$ cells were sorted by FACS and incubated for $16 \mathrm{~h}$ in a $\mathrm{CO}_{2}$ incubator. A fraction of these cells was suspended in CELLBANKER ${ }^{\circledR} 1$ (Takara Bio Inc., Shiga, Japan) and stored at $-80{ }^{\circ} \mathrm{C}$. The other cells were stimulated by anti-CD3/CD28 antibodies; these cells were broken into two groups: one group was exposed to Th17-inducing stimuli for $16 \mathrm{~h}$; the other group was not. Thereafter, the cells were fixed and permeabilized according to the method described above, and the expressions of intracellular Lck and pY505Lck were detected by FACS analysis.

\section{Carboxyfluorescein diacetate succinimidyl ester (CFSE) staining}

To observe long-term dynamic alternation of cell surface antigens, we performed a cell tracking assay using CellTrace TM CFSE Cell Proliferation Kit (Thermo Fisher Scientific). Sorted CD31 ${ }^{+}$ $\mathrm{CCR}^{-}$naive $\mathrm{CD}^{+} \mathrm{T}$ cells were stimulated by anti-CD3/CD28 antibodies overnight to initiate proliferation. These cells were resuspended in $1 \mathrm{ml}$ of $37^{\circ} \mathrm{C}$ PBS buffer and $1 \mu \mathrm{l}$, of CFSE was added.

Thereafter, these cells were incubated for 10 minutes at $37{ }^{\circ} \mathrm{C}$ in shading. The incubated cells were resuspended in $4 \mathrm{ml}$ incubation buffer and incubated for another 5 minutes in the same manner as above. The incubation buffer consisted of Roswell Park Memorial Institute (RPMI) -1640 medium (FujiFilm Wako Pure Chemical Corporation) supplemented with L-glutamine, phenol red, $10 \%$ fetal bovine serum (Biosera, Nuaille, France), and penicillin (100 U/ml)-streptomycin $(100 \mu \mathrm{g} / \mathrm{ml})$ (FujiFilm Wako Pure Chemical Corporation). After centrifugation and removal of the supernatant, the cells were seeded on a culture plate.

\section{Quantification and Statistical Analysis}

Statistical analyses were performed using $\mathrm{JMP}^{\circledR}$ Pro (version 14.0.0.) and R (version 3.6.0.). A value of $\mathrm{p}<0.05$ was considered significant in the two-tailed test. Student's t-test was performed to compare two independent groups. Bartlett's test was used to assess the equality of variance in different samples when comparing multiple groups. One-way analysis of variance was performed for comparing the mean values among multiple groups, and the Tukey test or Dunnett's test were used for post-hoc multiple comparisons. 


\section{Results}

\section{CD31- CCR6 $^{+}$Naive $\mathrm{CD}^{+}{ }^{+}$Tells were Precursors of Mature Th17 Cells}

Th17 cells are derived from $\mathrm{CCR}^{+}{ }^{+} \mathrm{CD} 4^{+} \mathrm{T}$ cells ${ }^{20)}$. Therefore, we examined the differences among the four subsets of naive $\mathrm{CD}^{+} \mathrm{T}$ cells expressing or not expressing CD31/CCR6 in response to Th17-inducing stimuli (IL-1 $\beta+$ IL-23). The gating strategy of naive CD31/CCR6 subsets is shown in Figure 1A. $\mathrm{CD}^{+} 1^{+} \mathrm{CCR}^{+}$cells composed a rare subset of these fractions. An enzyme-linked immunosorbent assay (ELISA) test administered on the culture supernatant of each subset stimulated by Th17-inducing stimuli and TCR stimuli (anti-CD3/CD28 antibodies) revealed that only $\mathrm{CD}^{-} 1^{-} \mathrm{CCR}^{+}$cells produced IL-17A $\left(\mathrm{p}<0.001\right.$ vs. CD31- ${ }^{-} \mathrm{CR} 6^{-}$cells and $\mathrm{p}<0.001$ vs. $\mathrm{CD}^{+} 1^{+} \mathrm{CCR}^{-}$cells, respectively) (Fig. 1B). Furthermore, the expression of RORC2, a transcription factor involved in the differentiation of human Th17 cells, was highest in the $\mathrm{CD}^{-} 1^{-} \mathrm{CCR}^{+}{ }^{+}$subset $\left(\mathrm{p}<0.05\right.$ vs. CD31- $\mathrm{CCR}^{-}$cells and $\mathrm{p}<0.05$ vs. CD $31^{+} \mathrm{CCR}^{-}$cells, respectively) (Fig. 1C). These results suggested that $\mathrm{CD} 31^{-} \mathrm{CCR}^{+}$naive type $\mathrm{CD}^{+}{ }^{+} \mathrm{T}$ cells were Th17 precursors that have the ability to differentiate into Th17 cells.
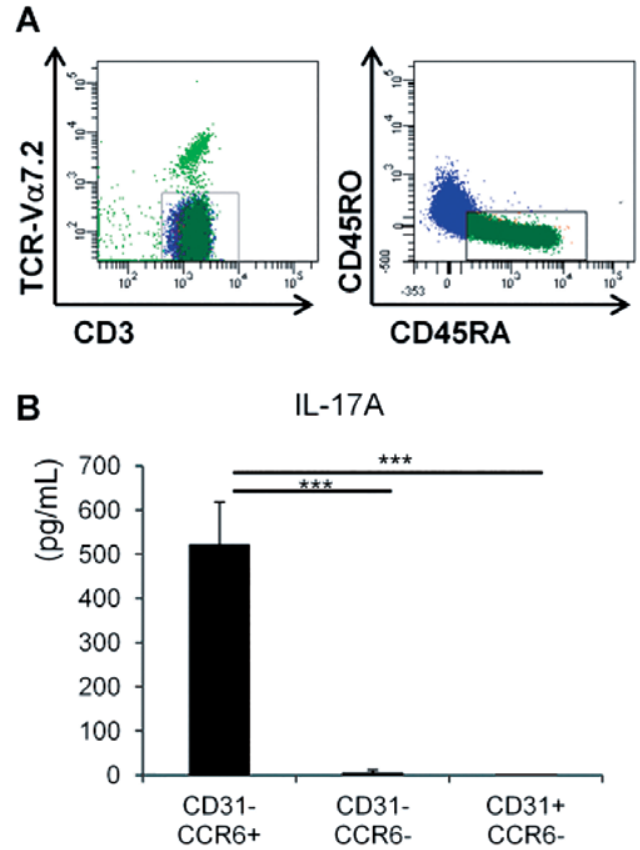
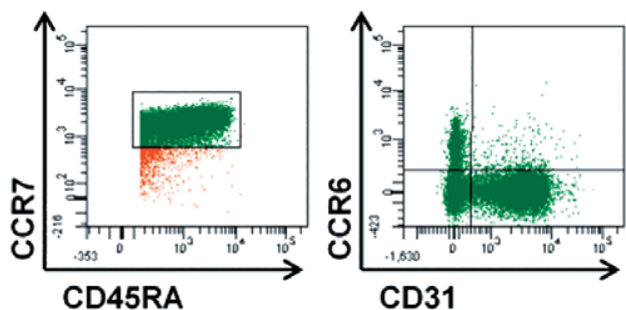

C

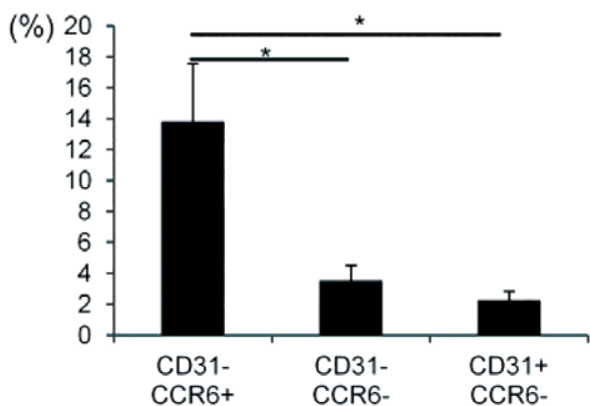

Fig. 1. Human Th17 Cells were Induced from Naive CD $31^{-}$CCR6 ${ }^{+}$Cells (A) The gating strategy of sorting CCR6/CD31 subsets: At first, the $\mathrm{CD}^{+}{ }^{+} \mathrm{TCR}-\mathrm{V} \alpha \mathrm{7} 2$ fraction was gated from PBMCs, and memory $\mathrm{T}$ cells $\left(\mathrm{CD} 45 \mathrm{RO}^{+} \mathrm{CD} 45 \mathrm{RA}^{-}\right)$were excluded. Thereafter, naive $\mathrm{T}$ cells $\left(\mathrm{CD}_{4} 5 \mathrm{RA}^{+} \mathrm{CCR}^{+}\right)$were gated from these cells, and naive CD31/ CCR6 subsets were sorted according to expressions of these antigens. (B) A comparison of IL-17A production $(n=4)$ and $(C)$ the expression of RORC2 $(n=3)$ in CCR6/CD31 subsets: Each subset was stimulated by anti-CD3/CD28 antibodies and Th17-inducing stimuli for 7 days. ELISA detected that the supernatant contained IL-17A after culturing each subset $\left(^{*}: \mathrm{p}<0.05,{ }^{* * *}: \mathrm{p}<0.001\right)$. Graphs without asterisks are considered not significant. The error bar shows SEM. 
CD31 Inhibited Activity of Lck

Newman et al described that SHP-2 bound to ITIM of the CD31 intracellular domain suppresses TCR downstream signaling molecules including Lck, one of the key signal molecules of IL-17 production ${ }^{21,22)}$. Expression of Lck and its inactive form (pY505-Lck) in CD31 ${ }^{+}$and CD31- cells was analyzed by FACS as shown in Figure 2. After TCR stimulation, Lck was phosphorylated at residue Y505 in $\mathrm{CD}^{+} \mathrm{T}$ cells and Lck was significantly converted into pY505Lck. (Fig. 2A). The ratio of pY505-Lck was compared between CD31 ${ }^{+}$and CD31- cells; CD31 ${ }^{+}$ cells expressed pY505-Lck significantly higher than CD31- cells after activation $(\mathrm{p}<0.01)$, while they were not significantly different before TCR activation (Fig. 2B). These results suggested that CD31 suppressed TCR signaling via Lck inactivation.

\section{CD31- CCR6 $^{+}$Cells were Derived from CD31 ${ }^{+}$CCR6 $^{-}$Cells}

Naive $\mathrm{T}$ cells delivered shortly after maturation in the thymus express CD3123). In addition, CCR6 is highly expressed in the memory fraction but only slightly expressed in the naive fraction ${ }^{24)}$. However, as shown in Figure 1, some CD31- naive $\mathrm{T}$ cells which expressed CCR6

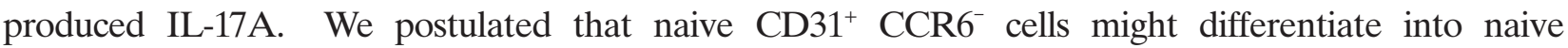
$\mathrm{CD}^{-} 1^{-} \mathrm{CCR}^{+}$cells in response to TCR stimuli and/or cytokines. Therefore, a cell tracking assay was conducted to label the $\mathrm{CD} 31^{+} \mathrm{CCR}^{-}$naive $\mathrm{CD}^{+} \mathrm{T}$ cells with carboxyfluorescein diacetate succinimidyl ester (CFSE). CFSE permeated into the cultured cells, and thereafter, was stable in the cells for at least 7 days. Since fluorescence intensity of CFSE is diluted along with cell division, the $\mathrm{CFSE}^{\text {low }}$ fraction contained the cells proliferated in response to TCR stimuli and Th17-inducing stimuli. As shown in Figure $3 \mathrm{~A}$, the $\mathrm{CD} 31^{+} \mathrm{CCR}^{-}$naive $\mathrm{CD}^{+} \mathrm{T}$ cells with CFSE were divided into the following three fractions four days after the labeling: $\mathrm{CFSE}^{\text {low }}$

A

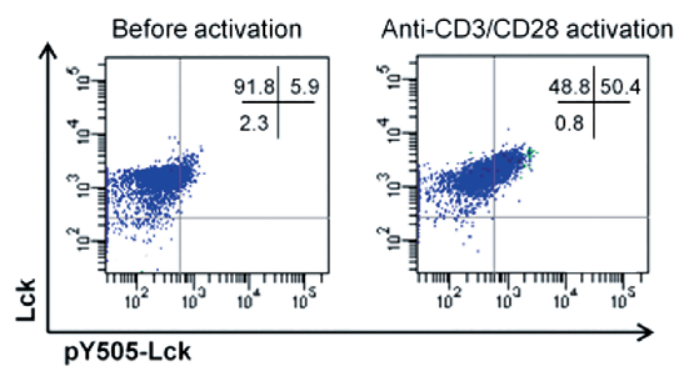

B

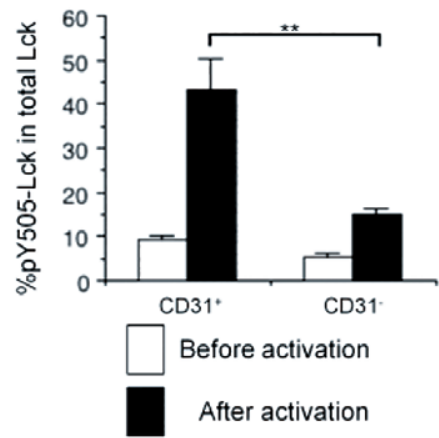

Fig. 2. CD31 Inhibited Activity of Lck.

(A) The expression of intracellular Lck and pY505-Lck in $\mathrm{CD}^{2} 1^{+}$naive $\mathrm{CD} 4^{+} \mathrm{T}$ cells before and after activation: Sample cells were stimulated by anti-CD3/CD28 antibodies. The numbers in the FACS analysis data indicate the rate of each fraction. (B) A comparison of pY505-Lck expression among CD31 ${ }^{+}$and $\mathrm{CD} 31^{-}$naive $\mathrm{CD} 4^{+} \mathrm{T}$ cells $(n=4)$ : Cells were stimulated by anti-CD3/CD28 antibodies and Th17-inducing stimuli $(* *: \mathrm{p}<0.01)$. The error bar shows SEM. 


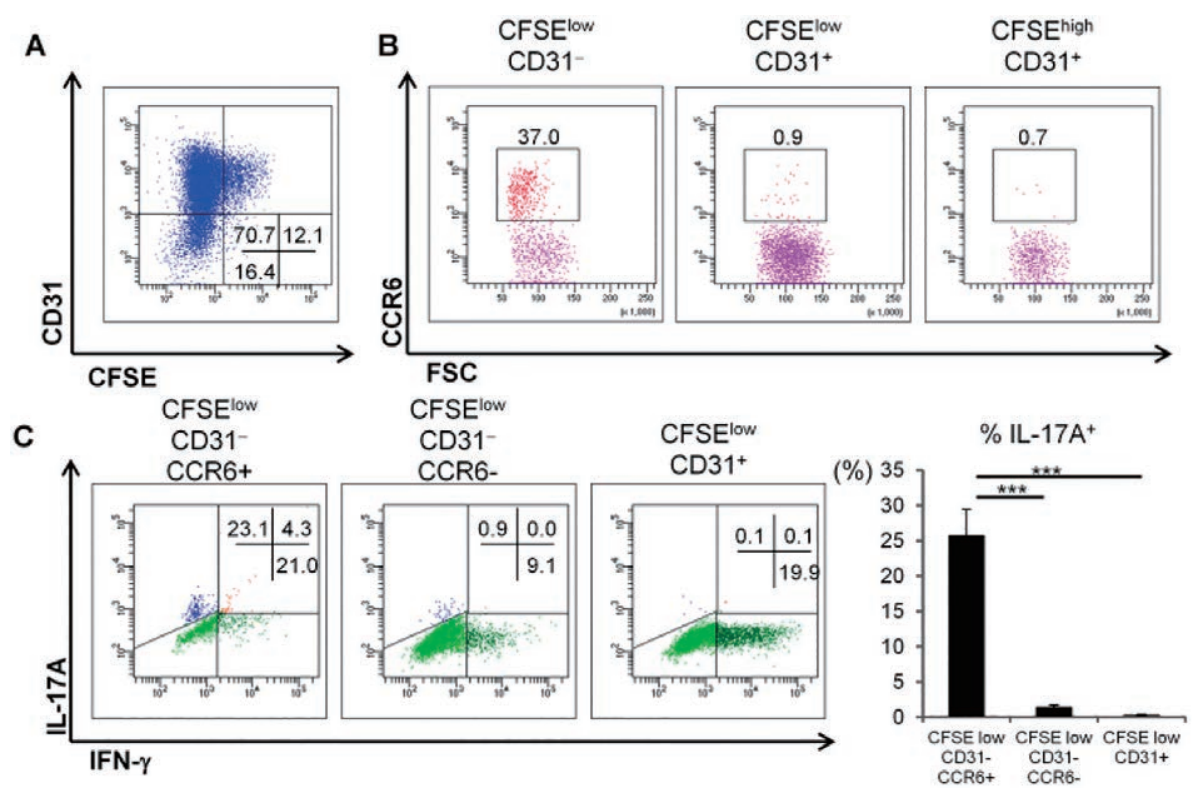

Fig. 3. $\mathrm{CD}^{-} 1^{-} \mathrm{CCR}^{+}$Cells were Derived from $\mathrm{CD}^{+} 1^{+} \mathrm{CCR}^{-}$Cells (A) The cell tracking assay for $\mathrm{CD}^{+} 1^{+} \mathrm{CCR}^{-}$naive $\mathrm{CD}^{+} \mathrm{T}$ cells using CFSE : Sample cells were stimulated by anti-CD3/CD28 antibodies and Th17-inducing stimuli for four days after CFSE staining. (B) The expression of CCR6 in each CD31/CFSE fraction: Three fractions were gated from Figure 3A. FSC (front scatter) was affected by cell size : larger cells had a higher FSC. (C) $\mathrm{CFSE}^{\text {low }} \mathrm{CD} 31^{-} \mathrm{CCR} 6^{+}$cells produced IL-17A in response to re-stimulation. $\mathrm{CFSE}^{\text {low }} \mathrm{CD}^{+}{ }^{+}, \mathrm{CFSE}^{\text {low }} \mathrm{CD}^{-} 1^{-} \mathrm{CCR}^{-}$and $\mathrm{CFSE}^{\text {low }} \mathrm{CD}^{-} 1^{-} \mathrm{CCR}^{+}$cells were sorted using FACS and re-stimulated by anti-CD3/ CD28 antibodies and Th17-inducing stimuli for five days. The numbers in the FACS analysis data indicate the rate of each fraction $(\mathrm{n}=3$ per group; $* * *: \mathrm{p}<0.001)$. Graphs without asterisks are considered not significant. The error bar shows SEM.

$\mathrm{CD}^{+} 1^{+}, \mathrm{CFSE}^{\text {low }} \mathrm{CD}^{-}$and CFSEhigh $\mathrm{CD}^{-} 1^{+}$. Importantly, the $\mathrm{CFSE}^{\text {low }} \mathrm{CD}^{-}$fraction specifically contained $\mathrm{CCR}^{+}$cells while only a small proportion of $\mathrm{CCR}^{+}$cells were detected in other fractions (Fig. 3B). Although $\mathrm{CFSE}^{\text {low }} \mathrm{CD}^{+}$cells and $\mathrm{CFSE}^{\text {low }} \mathrm{CD}^{+} 1^{-} \mathrm{CCR}^{-}$cells did not produce IL-17A, CFSE ${ }^{\text {low }} \mathrm{CD}^{-} \mathrm{CCR}^{+}$cells produced IL-17A ( $\mathrm{C}<0.001$ vs. $\mathrm{CFSE}^{\text {low }}$ $\mathrm{CD}^{+} 1^{+}$cells and $\mathrm{p}<0.001$ vs. $\mathrm{CFSE}^{\text {low }} \mathrm{CD}^{-} \mathrm{CCR}^{-}$, respectively) (Fig. 3C). Since freshly isolated $\mathrm{CD}^{2} 1^{+} \mathrm{CCR}^{-}$cells did not respond to Th17-inducing stimuli as shown in Figure 1, they did not produce IL-17 unless they were re-stimulated by TCR stimuli and Th17-inducing stimuli. Thus, all of those results suggested that $\mathrm{CD}^{-} 1^{-} \mathrm{CCR}^{+}$cells were derived from $\mathrm{CD}^{+} 1^{+} \mathrm{CCR} 6^{-}$ naive $\mathrm{CD}^{+} \mathrm{T}$ cells, and that they were Th17 precursors.

\section{IL-4 Prevented the Conversion of $\mathrm{CD} 1^{+} \mathrm{CCR6}^{-}$Cells into $\mathrm{CD}^{-} 1^{-} \mathrm{CCR}^{+}$Cells by TCR Stimuli}

Since Th17 cell differentiation from naive $\mathrm{CD} 4^{+} \mathrm{T}$ cells required downregulation of $\mathrm{CD} 31$ and expression of CCR6, we examined the effects of certain cytokines on Th17 differentiation in relation to the expression of these surface antigens. Purified CD $31^{+} \mathrm{CCR}^{-}$naive $\mathrm{T}$ cells were stimulated with cytokines that indicate Th differentiation (IL-1 $\beta$, IL-4, IL-6, IL-12, IL-23, and TGF- $\beta 1$ ). Under all conditions including the control, the expression of CD31 decreased; only 
cells exposed to IL-4 maintained substantial levels of CD31 expression ( $\mathrm{p}<0.001$ vs. control). Moreover, IL-4 did not upregulate CCR6 expression. In contrast, IL-6, IL-6 + TGF- $\beta$ 1, IL-12 and IL-23 upregulated CCR6 expression ( $\mathrm{p}<0.001, \mathrm{p}<0.001, \mathrm{p}<0.01$ and $\mathrm{p}<0.001$ vs. control, respectively) (Fig. 4A) . Additionally, the effects of cytokines (IL-1 $\beta+$ IL-23, IL-6 + TGF- $\beta 1$, IL-12, and IL-4) were tested on CD31- CCR6 ${ }^{-}$cells. IL-4 significantly induced CD31 expression ( $\mathrm{p}<0.001$ vs. IL-1 $\beta+$ IL-23, $\mathrm{p}<0.001$ vs. IL-6 + TGF- $\beta 1$ and $\mathrm{p}<0.05$ vs. IL-12, respectively) but only slightly induced CCR6 expression ( $\mathrm{p}<0.001$ vs. IL-1 $\beta+$ IL-23, $\mathrm{p}<0.001$ vs. IL-6 + TGF- $\beta 1$ and $\mathrm{p}<0.05$ vs. IL-12, respectively) (Fig. 4B). In contrast, other cytokine stimuli reciprocally regulated CD31 and CCR6 expression. These results suggested that IL-4 was the only suppressor of the differentiation from thymic naive $\mathrm{T}$ cells into Th17 precursors among all cytokines tested.

\section{Discussion}

The cell tracking assays presented here revealed that $\mathrm{CD} 31^{+} \mathrm{CCR} 6^{-}$thymic naive $\mathrm{CD} 4^{+} \mathrm{T}$ cells differentiated into $\mathrm{CD}^{-} 1^{-} \mathrm{CCR}^{+}$Th17 precursor cells. This result is consistent with the fact that IL-17-producing cells are present in the $\mathrm{CCR}^{+}$stem cell memory $\mathrm{T}$ cell fraction. The differentiation of Th17 precursor cells from thymic naive $\mathrm{CD}^{+} \mathrm{T}$ cells required TCR stimulation with some Th17-inducing cytokines including combinations of IL-1 $\beta$ plus IL-23 or IL-6 plus TGF- $\beta 1$. Therefore, the differentiation process of Th17 cells from human thymic naive CD $4^{+}$ $\mathrm{T}$ cells may require two steps, and IL-4 exhibit the inhibitory effect in the first step of Th17 differentiation.

Since CD31 modulates MAPK signaling and suppresses expressions of $\operatorname{ROR} \gamma \mathrm{t}^{25)}$, the reduction of CD31 contributes to $\mathrm{T}$ cells upregulating inflammatory $\mathrm{T}$ effector functions. Thus, the upregulation of CD31 by IL-4 causes T cells to have an inhibitory effect on inflammatory responses. Otherwise, the expression of CCR6 in naive $\mathrm{T}$ cells that was dependent on $\operatorname{ROR} \gamma \mathrm{t}^{26)}$ was downregulated by IL-4. These reports may explain why almost no CCR6 ${ }^{+}$cells exist in the $\mathrm{CD} 31^{+}$naive fraction. CCR6 is a chemokine receptor for CCL20 that is produced in skin or mucosal tissues ${ }^{27)}$. Thus, $\mathrm{CCR}^{+}$cells have important pathogenic roles in skin inflammatory diseases such as psoriasis. Our results demonstrate that IL-4 may have substantial inhibitory effects on Th17 differentiation which involves chronic inflammation leading to diseases such as psoriasis. A cell tracking assay showed that $\mathrm{CD} 31^{+}$naive $\mathrm{T}$ cells were differentiated into $\mathrm{CD} 31^{+}$cells and CD $31^{-}$cells. This result is consistent with a previous report ${ }^{28)}$, but the mechanism of downregulation of $\mathrm{CD} 31$ remains unclear. $\mathrm{CD} 31^{+}$thymic naive $\mathrm{T}$ cells may be heterogeneous because $\mathrm{CD} 31^{+}$naive $\mathrm{CD} 4 \mathrm{~T}$ cells were separated into $\mathrm{CD} 31^{+}$and $\mathrm{CD} 31^{-}$subsets after cell division.

Gattinoni et al reported that $\mathrm{T}_{\mathrm{SCM}}$ cells are capable of self-renewal and produce effector cytokines such as IFN- $\gamma$, IL-2, and tumor necrosis factor (TNF) $-\alpha$ in response to Staphylococcus enterotoxin $\mathrm{B}^{12)}$. Furthermore, $\mathrm{CCR}^{+}$naive $\mathrm{CD}^{+} \mathrm{T}$ cells that were included in the $\mathrm{T}_{\mathrm{SCM}}$ fraction produced IL-17A ${ }^{11)}$. Unlike in mice, human Th17 cells are not directly derived from naive $\mathrm{T}$ cells. Th17 cells have a pathological role in chronic inflammation but there may be a mechanism to avoid immediate differentiation into Th17 cells. Our study suggests that IL-4 is 
A

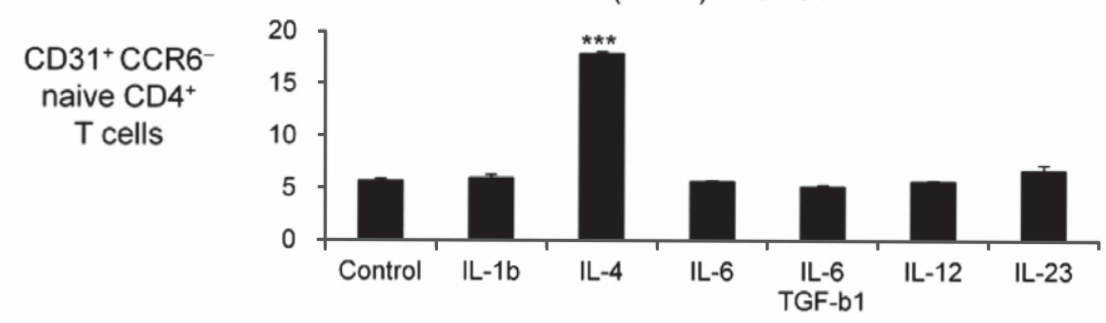

MFI of CCR6

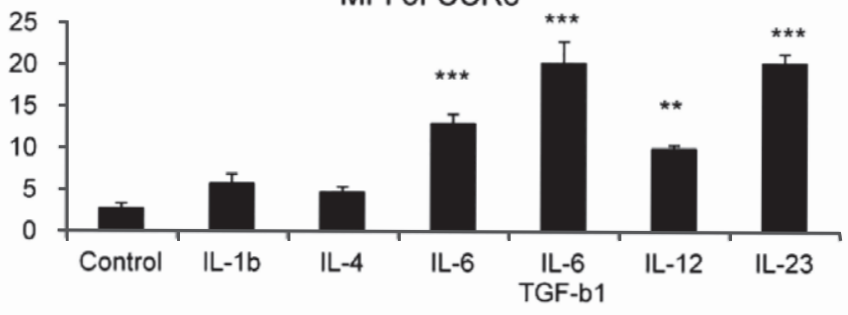

B

$\%$ CD31

\% CCR6

\section{CD31- ${ }^{-} C 6^{-}$ naive $\mathrm{CD}^{+}$ \\ T cells}
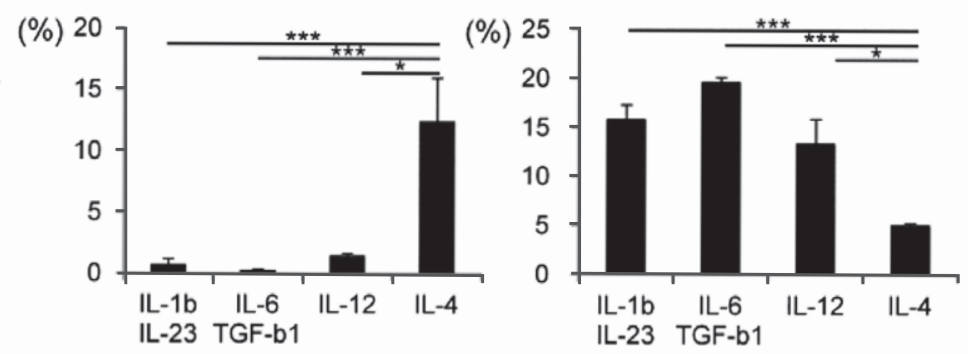

Fig. 4. IL-4 Regulated Expression of CD31 and CCR6

(A) A comparison of the effect of each cytokine on CCR6 and CD31 expressions of $\mathrm{CD}^{+} 1^{+} \mathrm{CCR} 6^{-}$naive $\mathrm{CD}^{+} \mathrm{T}$ cells: The cells were stimulated by each cytokine and anti-CD3/CD28 antibodies for four days. The y-axis indicates mean fluorescence intensity (MFI) ; $\left(\mathrm{n}=4\right.$ per group. ${ }^{* * *}: \mathrm{p}<0.001$ vs. control). (B) The alternation of CD31 and CCR6 expression on $\mathrm{CD}^{-} 1^{-} \mathrm{CCR}^{-}$naive $\mathrm{CD} 4^{+} \mathrm{T}$ cells was activated by each Th-specific inducing stimuli for four days. The $y$-axis indicates a positive rate of each antigen in total cells; $\left(\mathrm{n}=4\right.$ per group. $\left.{ }^{*}: \mathrm{p}<0.05,{ }^{* * *}: \mathrm{p}<0.001\right)$. The error bar shows SEM.

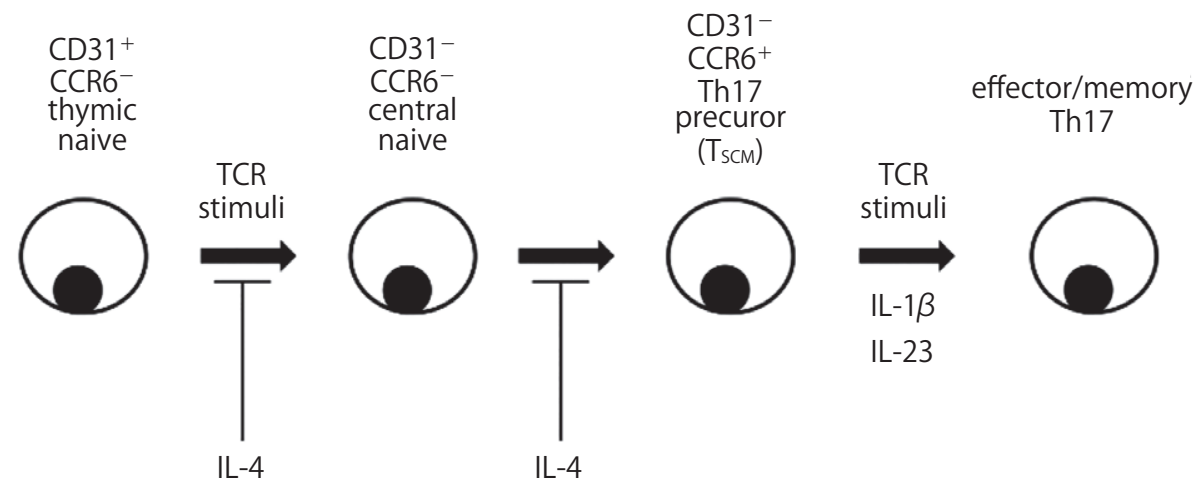

Fig. 5. The Model of Th17 Differentiation from Naive $\mathrm{CD}^{+} \mathrm{T}$ Cells 
a negative regulator of Th17 differentiation. Furthermore, IL-4 has an anti-inflammatory effect because it induces an IL-1 antagonist ${ }^{29)}$. Suppression of Th17 differentiation by IL-4 may be involved in the regulation of chronic inflammation.

In conclusion, $\mathrm{CD}^{-}{ }^{-} \mathrm{CCR}^{+}{ }^{+} \mathrm{T}_{\mathrm{SCM}}$ cells derived from naive $\mathrm{CD} 31^{+} \mathrm{CCR}^{-}$cells were the precursor for human Th17 cells, and IL-4 suppressed the differentiation of Th17 precursors due to increasing CD31 expression and decreasing CCR6 expression. Although it is known that Th17 precursors develop into central memory cells or effector memory cells that directly involve pathogenesis of inflammatory diseases, our results constitute novel findings on the regulation of differentiation of naive $\mathrm{CD} 4^{+} \mathrm{T}$ cells into Th17 cells in humans; this may provide hints for further elucidation of the differentiation process of Th17 cells and of the pathology of Th17 cellrelated diseases.

\section{Conflict of interest disclosure}

The authors have no conflict of interest disclosure.

\section{References}

1) Mosmann TR, Coffman RL. TH1 and TH2 cells: different patterns of lymphokine secretion lead to different functional properties. Аппи Rev Immunol. 1989;7:145-173.

2) Langrish CL, Chen Y, Blumenschein WM, et al. IL-23 drives a pathogenic $T$ cell population that induces autoimmune inflammation. $J$ Exp Med. 2005;201:233-240.

3) Nestle FO, Kaplan DH, Barker J. Psoriasis. N Engl J Med. 2009;361:496-509.

4) Komatsu N, Okamoto K, Sawa S, et al. Pathogenic conversion of Foxp3 $(+)$ T cells into TH17 cells in autoimmune arthritis. Nat Med. 2014;20:62-68.

5) Fujino S, Andoh A, Bamba S, et al. Increased expression of interleukin 17 in inflammatory bowel disease. Gut. 2003;52:65-70.

6) Ivanov II, McKenzie BS, Zhou L, et al. The orphan nuclear receptor RORgammat directs the differentiation program of proinflammatory IL-17+ T helper cells. Cell. 2006;126:1121-1133.

7) Castro G, Liu X, Ngo K, et al. RORgamma t and RORalpha signature genes in human Th17 cells. PLoS One. 2017;12:e181868. (accessed 2019 Dec 19) Available from: https://www.ncbi.nlm.nih.gov/pmc/articles/PMC5538713/pdf/ pone.0181868.pdf

8) Harrington LE, Hatton RD, Mangan PR, et al. Interleukin 17-producing CD4 $(+)$ effector $\mathrm{T}$ cells develop via a lineage distinct from the $\mathrm{T}$ helper type 1 and 2 lineages. Nat Immunol. 2005;6:1123-1132.

9) Park $\mathrm{H}, \mathrm{Li} \mathrm{Z}$, Yang XO, et al. A distinct lineage of CD4 T cells regulates tissue inflammation by producing interleukin 17. Nat Immunol. 2005;6:1133-1141.

10) van Beelen AJ, Zelinkova Z, Taanman-Kueter EW, et al. Stimulation of the intracellular bacterial sensor NOD2 programs dendritic cells to promote interleukin-17 production in human memory T cells. Immunity. 2007;4:660-669.

11) Takeshita M, Suzuki K, Kassai Y, et al. Polarization diversity of human CD4 $(+)$ stem cell memory T cells. Clin Immunol. 2015;159:107-117.

12) Gattinoni L, Lugli E, Ji Y, et al. A human memory $\mathrm{T}$ cell subset with stem cell-like properties. Nat Med. 2011;17:1290-1297.

13) Newman PJ. The biology of PECAM-1. J Clin Invest. 1997;99:3-8.

14) Kohler S, Thiel A. Life after the thymus: $\mathrm{CD} 31(+)$ and $\mathrm{CD} 31(-)$ human naive $\mathrm{CD} 4(+)$ T-cell subsets. Blood. 
2009;113:769-774.

15) Stulnig T, Maczek C, Bock G, et al. Reference intervals for human peripheral blood lymphocyte subpopulations from 'healthy' young and aged subjects. Int Arch Allergy Immunol. 1995;108:205-210.

16) Viret C, Wong FS, Janeway CA Jr. Designing and maintaining the mature TCR repertoire: the continuum of selfpeptide:self-MHC complex recognition. Immunity. 1999;10:559-568.

17) Witherden D, van Oers N, Waltzinger C, et al. Tetracycline-controllable selection of CD4 $(+) \mathrm{T}$ cells: half-life and survival signals in the absence of major histocompatibility complex class II molecules. J Exp Med. 2000;191:355364.

18) Demeure CE, Byun DG, Yang LP, et al. CD31 (PECAM-1) is a differentiation antigen lost during human CD4 T-cell maturation into Th1 or Th2 effector cells. Immunology. 1996;88:110-115.

19) Newton-Nash DK, Newman PJ. A new role for platelet-endothelial cell adhesion molecule-1 (CD31): inhibition of TCR-mediated signal transduction. J Immunol. 1999;163:682-688.

20) Annunziato F, Cosmi L, Santarlasci V, et al. Phenotypic and functional features of human Th17 cells. $J$ Exp Med. 2007;204:1849-1861.

21) Newman DK, Hamilton C, Newman PJ. Inhibition of antigen-receptor signaling by platelet endothelial cell adhesion molecule-1 (CD31) requires functional ITIMs, SHP-2, and p56 (lck). Blood. 2001;97:2351-2357.

22) Zhu Y, Gumlaw N, Karman J, et al. Lowering glycosphingolipid levels in CD4 $(+) \mathrm{T}$ cells attenuates T cell receptor signaling, cytokine production, and differentiation to the Th17 lineage. J Biol Chem. 2011;286:14787-14794.

23) Kimmig S, Przybylski GK, Schmidt CA, et al. Two subsets of naive $\mathrm{T}$ helper cells with distinct $\mathrm{T}$ cell receptor excision circle content in human adult peripheral blood. J Exp Med. 2002;195:789-794.

24) Liao F, Rabin RL, Smith CS, et al. CC-chemokine receptor 6 is expressed on diverse memory subsets of T cells and determines responsiveness to macrophage inflammatory protein 3 alpha. J Immunol. 1999;162:186-194.

25) Flego D, Severino A, Trotta F, et al. Altered CD31 expression and activity in helper $\mathrm{T}$ cells of acute coronary syndrome patients. Basic Res Cardiol. 2014;109:448.

26) Hirota K, Yoshitomi H, Hashimoto M, et al. Preferential recruitment of CCR6-expressing Th17 cells to inflamed joints via CCL20 in rheumatoid arthritis and its animal model. J Exp Med. 2007;204:2803-2812.

27) Homey B, Dieu-Nosjean MC, Wiesenborn A, et al. Up-regulation of macrophage inflammatory protein-3 alpha/ CCL20 and CC chemokine receptor 6 in psoriasis. J Immunol. 2000;164:6621-6632.

28) Demeure CE, Byun DG, Yang LP, et al. CD31 (PECAM-1) is a differentiation antigen lost during human CD4 T-cell maturation into Th1 or Th2 effector cells. Immunology. 1996;88:110-115.

29) Orino E, Sone S, Nii A, et al. IL-4 up-regulates IL-1 receptor antagonist gene expression and its production in human blood monocytes. J Immunol. 1992;149:25-31.

[Received December 27, 2019: Accepted January 14, 2020] 